\title{
JOURNAL.RU
}

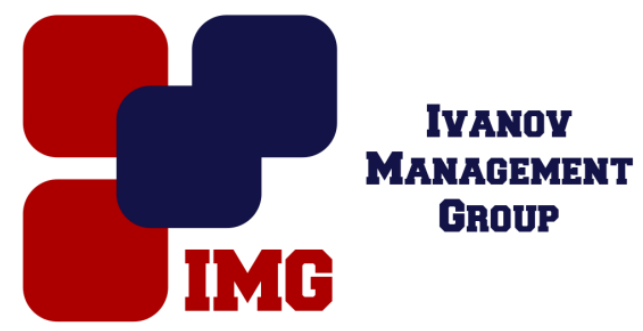

Сагитдинова Ю.Р.

СГТУ им. Ю.А. Гагарина

Саратов, Россия

doi: $10.18411 / \mathrm{lj}-31-07-2017-28$

idsp 000001:1j-31-07-2017-28

\section{Разработка структурно-функциональной схемы МАК для лазерной хирургии глаз}

Научный руководитель: Пичхидзе С.Я.

Лазерная хирургия глаза это передовое направление современной офтальмологии. Существуют хирургические комплексы коррекции зрения, в которых врач не только вводит исходные параметры для проведения операции, но и непосредственно устанавливает и центрирует аппарат над глазом пациента. Автоматизация использует саморегулирующие технические средства и математические методы, с целью освобождения человека от участия в процессах работы технического средства, а так же позволяет повысить производительность труда, улучшить качество продукции и оптимизировать процессы управления $[1$, 2].

Целью данной работы является: разработка структурно-функциональной схемы медицинского автоматизированного комплекса (МАК) для лазерной хирургии глаз. Автоматизация данного диагностического комплекса позволяет максимально облегчить работу врача, создать более комфортные условия для пациента и уменьшить время проведения операции.

Работа данного медицинского автоматизированного комплекса основана на проведении лазерной операции глаза с предварительно стабилизированным лечебным лазерным блоком, рис.1. Разработанный МАК состоит из нескольких основных элементов: механизированное кресло-кровать (1); механизм перемещения лечебного лазерного блока (2); механизм перемещение 
видеокамеры (3). Лечебный блок, рис. 2, состоит из следующих элементов: источники питания лазеров; лазер оптический $\mathrm{He}-\mathrm{Ne}$ (Л2); лазер хирургический CO2 (Л1); зеркала для направления лазерного луча (31, 32); датчик мощности хирургического лазера (Д26); заслонка для регулировки мощности хирургического лазера (За); видео-датчик положения (Д25); линза фокусирующая (ФЛ).

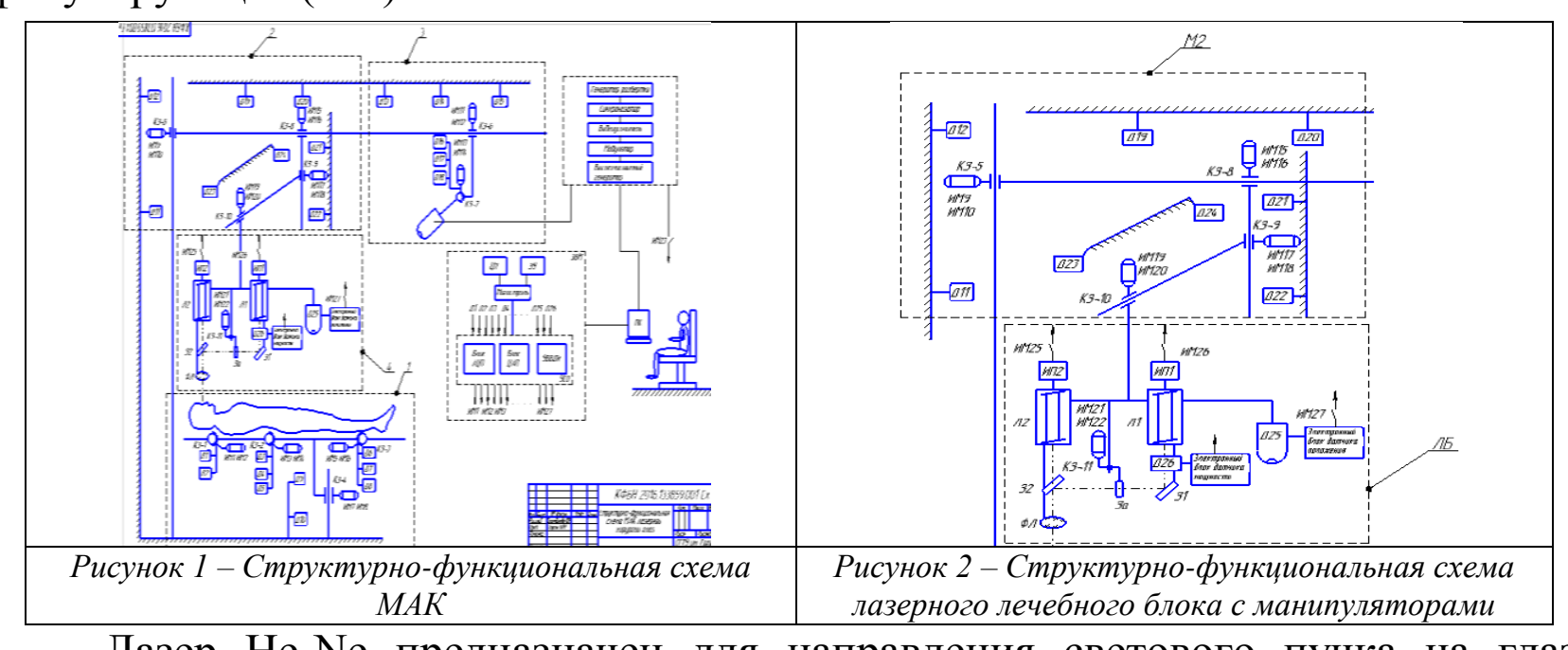

чтобы в дальнейшем правильно позиционировать $\mathrm{CO} 2$ лазер. Длина волны его излучения составляет 630 нм, мощность 50 мВт. Лазер CO2 предназначен непосредственно для проведения хирургической процедуры, то есть выжигания участка роговицы глаза. Поверхностное воздействие лазера позволяет иссекать биоткань без глубокого ожога. В СО2-лазерах для хирургических целей применяют так называемый "суперимпульсный" режим (super impulse), при котором лазерное излучение имеет вид пачки коротких, но в 2-3 раза более мощных импульсов в сравнении со средней мощностью непрерывного лазера, длина волны 10,6 мкм, мощность - 30 Вт, частота импульсов - 2 мс.

Выводы: разработана структурно-функциональная схема МАК для лазерной хирургии глаз.

\section{$* * *$}

1. Справочник по лазерной технике / пер. с нем. - М.: Энергоатомиздат, 1991. -544 c.

2. Таран В.М. Конструирование деталей, узлов и элементов биотехнических систем: учебное пособие / В.М. Таран, О.А. Дударева. - М.: Прондо, 2015. - 306 с.

3. Насанова А.А., Муктаров О.Д., Буров А.М., Пичхидзе С.Я. Исследование биологического карбонат-гидроксиапатита. В сборнике: Будущее науки - 2015. Сборник научных статей 3-й Международной молодежной научной конференции в 2-х томах. Ответственный редактор: Горохов А.А.. 2015. С. 210-211. 